\title{
Distribution of Aspergillus flavus in the maize fields and drying facilities in Thailand: An examination in dry season (January-February, 1986)
}

\author{
M. Saito*1, K. Kawasugi*2, P. Siriacha*3, O. Tsuruta*1, D. Buangsuwon*3, \\ T. GoTo*1, M. MANABE*1, and K. PANAWAS ${ }^{* 3}$
}

\begin{abstract}
斉藤 道彦*1, 川杉 正一*2, Prisnar SiRIACHA*3, 鶴田 理*1, Dara BuANGSUWON*3, 後藤 哲久*1，真鍋勝*1，Kanoknij PANAWAS*3: タイ国のトゥモロコシ直場 および乾燥場における Aspergillus flavus の分布一乾季 (1986年 1 月〜 2 月) の調査
\end{abstract}

\section{Summary}

In order to clarify environmental factors that contribute to invasion of Aspergillus flavus, one of the aflatoxin-producing fungi, into the maize kernels, the distribution of $A$. flavus as the potential inoculum in soil and atomosphere of maize fields and drying or storage facilities was examined in 8 provinces of Thailand during dry season (January-February, 1986). A. flavus was isolated from almost all of the soil samples. Although the numbers were quite different among the positive samples, it was concluded that the soil from middlemen's drying facilities and farmer's barn was, in general, more heavily contaminated than those from the fields. No A. flavus spore was trapped in $90 \mathrm{~L}$ of air samples from the 21 fields examined. On the contrary, A. flavus spores were trapped in almost all of the middlemen's drying facilities, although their numbers were smaller than those detected on the same locations in rainy season.

It has been accepted, especially in the U.S.A., that the preharvest infection of maize with Aspergillus flavus Link, one of the aflatoxin-producing fungi, results in subsequent contamination of aflatoxins ${ }^{1-5}$. It is, however, not clear in Thailand because there is no approach to study environmental factors which influence invasion of $A$. flavus into maize kernels and subsequent aflatoxin contamination in the field and during harvest and storage. Basing upon the view that inoculum level of a toxin-producer may influence the extent of incidence of contamination, we started the investigation on geographical distribution and seasonal changes of $A$. flavus populations in soil and its air-borne spores at maize fields

*1 National Food Research Institute, Ministry of Agriculture, Forestry and Fisheries (Yatabe, Ibaraki 305)

農林水産省食品総合研究所（广305 茨城県筑波郡谷田部町観音台2-1-2）

*3 Tropical Agriculture Research Center, Ministry of Agriculture, Forestry and Fisheries (Yatabe, Ibaraki 305)

農林水産省熱帯農業研究センター（テ305 茨城県筑波郡谷田部町大わし1-2）

*2 Seed and Postharvest Pathology Branch, Department of Agriculture (Bangkhen, Bangkok, Thailand)

タイ国農業局種子およびポストハーベスト病理研究室（タイ国バンコク市バンケン） 
and drying or storage facilities, as a collaborative project between the Department of Agriculture of Thailand and the Tropical Agriculture Research Center (TARC) of Japan.

The first survey during the rainy season has been already reported ${ }^{6,7}$. In this paper, the results obtained from a continued examination in dry season (January-February, 1986) are described.

\section{Materials and Methods}

Soil and air samples examined for A. flavus populations were collected in Chiang Rai, Chiang Mai, Phetchabun, Phitsanulok, Nakhon Sawan, Lop Buri, Nakhon Ratchasima and Rayong provinces during January to February of 1986 (Fig. 1). The soil samples were collected from 20 maize fields (12 of farmers and 8 in the regional research centers or experiment stations), a flower field, 2 cassava fields in Rayong province where maize is rarely planted, and a farmer's barn and 4 middlemen's drying facilities for maize. The middlemen's drying facilities examined in this study consist of a flat concreted open space surrounded with walls, where maize is dried in the sun or warehouses.

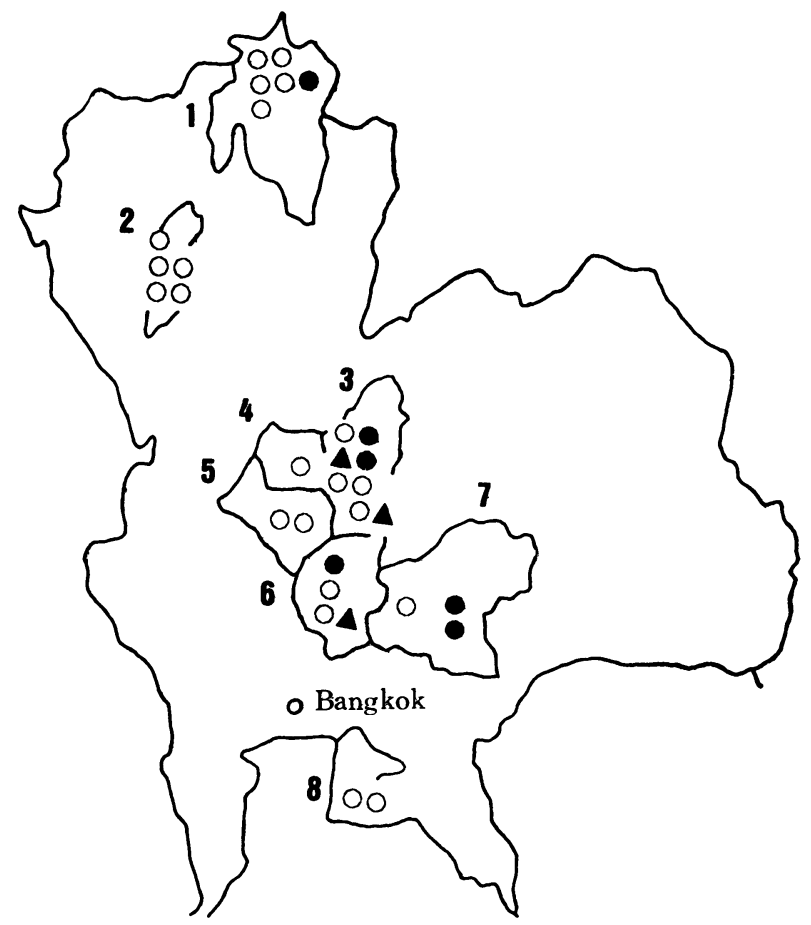

1. Chiang Rai 2. Chiang Mai

3. Phetchabun

4. Phitsanulok 5. Nakhon Sawan 6. Lop Buri

7. Nakhon Ratchasima 8. Rayong

Fig. 1. Map showing the provinces for collecting soil and air samples O: field; ๑: middleman's drying facility; $\Delta$ : farmer's barn. 
The samples were collected at 3 points within each sampling site in the depth of $0-10$ $\mathrm{cm}$. From each sample, $0.5 \mathrm{~g}$ of soil was suspended in $100 \mathrm{ml}$ sterile water and shaken for $15 \mathrm{~min}$ on shaker, then $1 \mathrm{ml}$ of suspension was pipetted into 5 Petri dishes $(9 \mathrm{~cm}$ in diameter) and molten medium was poured and mixed thoroughly. The medium consisted of $45 \mathrm{~g}$ malt agar (Difco), $30 \mathrm{~g} \mathrm{NaCl}, 50 \mathrm{mg}$ chloramphenicol, $30 \mathrm{mg}$ rose bengal, $1 \mathrm{mg} \mathrm{2,6-}$ dichloro-4-nitroaniline and $1000 \mathrm{ml}$ water. The dishes were incubated at $30^{\circ} \mathrm{C}$ for 5 days and growing $A$. flavus colonies were counted.

Air samples in the 21 fields, 6 warehouses at middlemen's drying facilities and 3 farmers' barns were collected by using an air sampler ("SAS" Bacteriological Air Sampler, Pool Bioanalysis Italiana Co.), operating for $1 \mathrm{~min}$ ( $90 \mathrm{~L}$ of air was sucked). The numbers of $A$. flavus colonies which grew from trapped spores on agar plates placed in the sampler were counted. The medium consisted of $39 \mathrm{~g}$ PDA (Difco), $30 \mathrm{mg}$ rose bengal, $50 \mathrm{mg}$ chloramphenicol and $1000 \mathrm{ml}$ water.

\section{Results and Discussion}

\section{Soil}

The results of examination on A. flavus populations were presented in Table 1. Out of the 27 soil samples, A. flavus was detected from 26 samples. One negative sample was from a maize field in Phetchabun province. The populations in soils from fields and middlemen's drying facilities were $0-3,533 \mathrm{cfu} / \mathrm{g}$ (mean 335) and 1,688-7,884 cfu/g (mean 3,757), respectively. The soil in the farmer's barn yielded $3,237 \mathrm{cfu} / \mathrm{g}$. These results showed that the soils in both the middlemen's drying facilities and farmer's barn were heavily contaminated with $A$. flavus, although the latter had been examined on only one case. Although the $A$. flavus populations in soils significantly varied with different fields, the detection of higher levels of $A$. flavus populations from some locations was noticeable. However, no evidence of geographical difference in the A. flavus populations was observed. In the same locations, moreover, the results obtained from rainy ${ }^{6}$ ) and dry seasons could not show any seasonal change in the $A$. flavus populations in the soils.

\section{Atomosphere}

Table 1 shows the results on measurement of the numbers of $A$. flavus spores in the air samples. No $A$. flavus spore was trapped in all the 21 fields surveyed. On the contrary, in 5 of 6 samples from middlemen's warehouses, A. flavus spores were detected in range of $9-80 \mathrm{cfu} / 90 \mathrm{~L}$ of air (mean 39). Two samples from 3 farmers' barns yielded the A. flavus colonies, but the numbers were very low: 1 and 3, respectively.

Tsuruta et al. ${ }^{7}$, examining the distribution of $A$. flavus spores in rainy season (September, 1985), showed that only one of the 7 air samples from maize fields was positive for A. flavus ( $2 \mathrm{cfu} / 90 \mathrm{~L}$ of air), whereas those of 2 middlemen's warehouses yielded $276 \mathrm{cfu}$ and $482 \mathrm{cfu}$, respectively. The quite similar results that little or no A. flavus spores were detected from the air samples in the fields were obtained in two seasonal examinations (rainy in 1985 and dry in 1986). The A. flavus spores were trapped in almost all of the middlemen's warehouses in both examinations, although the numbers detected in 
Table 1. Populations of Aspergillus flavus in soil and atomosphere

\begin{tabular}{|c|c|c|c|}
\hline \multirow{2}{*}{ Province } & \multirow{2}{*}{ Sampling site } & \multicolumn{2}{|c|}{ A. flavus colony counts } \\
\hline & & Soil $(1 \mathrm{~g})$ & $\operatorname{Air}(90 \mathrm{~L})$ \\
\hline \multirow[t]{6}{*}{ Chiang Rai } & Maize field (Farmer) & 282 & 0 \\
\hline & Maize field (Research Center*1) & 208 & 0 \\
\hline & Flower field (Research Center*1) & 68 & 0 \\
\hline & Middleman's drying facility & 3,723 & 0 \\
\hline & Maize field (Farmer) & 193 & 0 \\
\hline & Maize field (Farmer) & 229 & 0 \\
\hline \multirow[t]{5}{*}{ Chiang Mai } & Maize field (Farmer) & 1,087 & 0 \\
\hline & Maize field (Farmer) & 218 & 0 \\
\hline & Maize field (Research Center*2) & 79 & 0 \\
\hline & Maize field (Research Center*2) & 46 & - \\
\hline & Maize field (Farmer) & 361 & 0 \\
\hline Phitsanulolk & Maize field (Experiment Station ${ }^{* 3}$ ) & 9 & 0 \\
\hline \multirow[t]{2}{*}{ Nakhon Sawan } & Maize field (Farmer) & 2 & 0 \\
\hline & Maize field (Research Center ${ }^{* 4}$ ) & 15 & 0 \\
\hline \multirow[t]{8}{*}{ Phetchabun } & Maize field (Farmer) & 3,533 & - \\
\hline & Maize field (Experiment Station*5) & 14 & 0 \\
\hline & Farmer's barn & - & 3 \\
\hline & Middleman's drying facility & - & 9 \\
\hline & Middleman's drying facility & 7,884 & 48 \\
\hline & Maize field (Famer) & 12 & 0 \\
\hline & Farmer's barn & 3,237 & 0 \\
\hline & Maize field (Farmer) & 0 & 0 \\
\hline \multirow[t]{4}{*}{ Lop Buri } & Middleman's drying facility & 1,733 & 80 \\
\hline & Farmer's barn & - & 1 \\
\hline & Maize field (Farmer) & 291 & 0 \\
\hline & Maize field (Experiment Station*6) & 87 & 0 \\
\hline \multirow[t]{3}{*}{ Nakhon Ratchasima } & Middleman's drying facility & 1,686 & 14 \\
\hline & Middleman's drying facility & - & 42 \\
\hline & Maize field (Famer) & 7 & 0 \\
\hline \multirow[t]{2}{*}{ Rayong } & Cassava field (Research Center*7) & 188 & 0 \\
\hline & Cassava field (Farmer) & 440 & 0 \\
\hline
\end{tabular}

${ }^{* 1}$ Chiang Rai Field Crop Research Center; ${ }^{* 2}$ Chiang Mai Horticulture Research Center; ${ }^{* 8}$ Phitsanulok Field Crop Experiment Station; ${ }^{* 4}$ Nakhon Sawan Field Crop Research Center; ${ }^{* 5}$ Phetchabun Field Crop Experiment Station; ${ }^{* 6}$ Lop Buri Field Crop Experiment Station; ${ }^{* 7}$ Rayong Field Crop Research Center.

the examination of dry season were much smaller than those detected in rainy season.

Some papers ${ }^{8-11)}$ on the numbers of $A$. flavus spores in the atomosphere of maize fields in the U.S.A. showed that the numbers of air-borne spores of $A$. flavus might not be so high, even though they may depend on the sampling method, weather and the other factors. This means that the low occurrence of $A$. flavus spores may not always exclude the possibility of preharvest incidence of aflatoxin contamination in maize. Nevertheless, the rather high levels of air-borne spores of $A$. flavus in the warehouses of middlemen's drying facilities suggested that the drying and storage processes should be improved for preventing the aflatoxin contamination of maize in Thailand. 


\section{Acknowledgements}

We wish to express our thanks to Mr. Kenji Tanaka for the discussion of the problem. Thanks are also due to Mr. Suparat Kositcharoenkul and Miss Pattamarat Limpsisawad for their aid in collecting the samples.

\section{References}

1) Rambo, G.W., Tuite, J., Caldwell, R.W.: Cereal Chem., 51, 848 (1974).

2) Anderson, H.W., Nehring, E.W., Wichser, W. R.: 'J. Agric. Food Chem., 23, 775 (1975).

3) Zuber, M.S., Calvert, O.H., Lillehoj, E.B., Kwolek, W.F.: Phytopathology, 66, 1120 (1976).

4) Lillehoj, E. B., Kwolek, W.F., Zuber, M.S., Calvert, O.H., Horner, E.S., Widstrom, N.W., Guthrie, W.D., Scott, G.E., Thompson, D.L., Findley, W.R., Bockholt, A. J.: Cereal Chem., 55, 1007 (1978).

5) Lillehoj, E. B., Kwolek, W.F., Horner, E.S., Widstrom, N.W., Josephson, L.M., Franz, A.O., Catalano, E. A.: Cereal Chem., 57, 255 (1980).

6) Tsuruta, O., Goto, T., Saito, M., Siriacha, P., Panawas, K., Buangsuwon, D.: Proc. Jpn. Assoc. Mycotoxicol., 23, 59 (1986).

7) Tsuruta, O., Goto, T., Siriacha, P., Saito, M., Buangsuwon, D.: Proc. Jpn. Assoc. Mycotoxicol., 23, 62 (1986).

8) Bothast, R.J,, Beuchat, L.R., Emswiller, B.S., Johnson, M.G., Pierson, M. D.: Appl. Environ. Microbiol., 35, 627 (1978).

9) Holtmyer, M.G., Wallin, J. R.: Phytopathology, 70, 325 (1980).

10) Holtmyer, M.G.: Plant Disease, 65, 58 (1981).

11) Jones, R.K., Duncan, H.E., Hamilton, P. B.: Phytopathology, 71, 810 (1981). 